\title{
PERAN HAKIM DALAM PENEGAKAN \\ ETIKA DAN PROFESI HUKUM
}

KAJIAN PUSTAKA

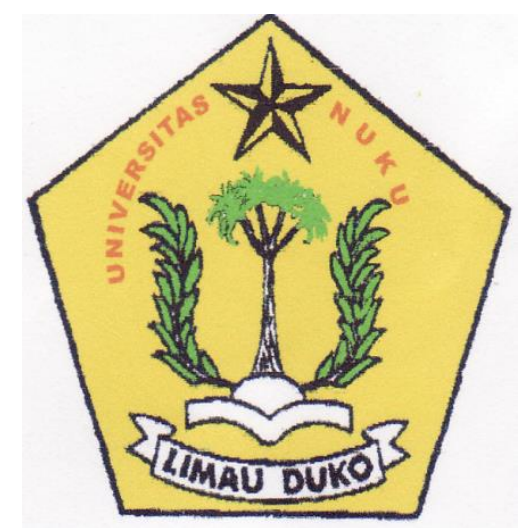

HAKIM

e-mail : hakimnuku@gmail.com

\section{F A K U L T A S H U K U M UNIVERSITAS NUKU 2016}




\section{ABSTRAK}

Etika profesi merupakan tuntunan bagi seorang hakim dalam menjalankan tugasnya hal itu juga sudah tertuang dalam arah kebijakan bidang hukum pada point (5) sebagaimana yang termuat dalam Tap MPR RI Nomor II/MPR/1999 Tentang Garis-garis Besar Haluan Negara, yaitu meningkatkan integritas moral dan keprofesionalan aparat penegak hukum, termasuk kepolisian negara kepolisian Republik Indonesia untuk menumbuhkan kepercayaan masyarakat dengan meningkatkan kesejahteraan yang efektif.

Etika prosfesi yang tertuang dalam etika hakim itu merupakan aturan, patokan, atau hukum yang harus dipergunakan dan pegang teguh oleh para hakim dalam penghayatan profesi mereka sebagai penegak hukum dan keadilan. Hal ini juga akan dipergunakan untuk memakai baik buruknya tindak hakim dalam menjalankan tugasnya bahkan juga menjadi kriteria moral dalam penegak hukum.

Sedangkan masalah yang di bahas dalam penulisan ini adalah Bagaimana fungsi dan peranan etika profesi hukum bagi hakim dalam penegakan hukum? Metode penelitian yang digunakan dalam penelitian ini adalah yuridis normatif dengan pendekatan perundang-undangan dan kasus. Kesimpulanya dalam penulisan ini adalah

Fungsi dan peranan etika profesi hukum bagi hakim dalam hal penegakan hukum sebagai pedoman setiap hakim dalam melaksanakan tugas sebagai hakim dalam memberikan suatu keputusan harus benar-benar memperhatikan etika serta asas keadilan.

Kata kunci : Penegak hukum; Etika Profesi Hakim 


\section{PENDAHULULAN}

\section{A. Latar Belakang Masalah}

Setiap bangsa yang merdeka memiliki cita-cita yang luhur dalam memberikan kedamaian dan keadilan kepada masyarakatnya begitu pula Bangsa Indonesia. Dalam hal ini penegak hukum memiliki peranan yang penting untuk mewujudkan ide-ide tentang keadilan, kepastian hukum dan pemanfaatan sosial menjadi suatu kenyataan.

Secara normatif Bangsa Indonesia telah merumuskan perundangundangan (aturan hukum) yang cukup. Namun hal yang mendasar yang banyak berperan dalam pembentukan peradaban hukum semakin terperosot hal ini disebabkan karena orang-orang yang berada dibalik hukum. Kondisi ini tidak dapat dipungkiri bahwa sebagian besar penegak hukum dilanda krisis kesadaran moral, secara mendalam kondisi ini dapat dilihat bahwa penegak hukum justru banyak terlihat dalam pelanggaran hukum.

Secara konsepsional, maka inti dan arti penegakan hukum terletak pada kegiatan hubungan nilai-nilai yang terurai di dalam kaidah-kaidah hukum dan merealisasikan dalam sikap serta tindak sebagai rangkaian penjabaran nilai tahap akhir, untuk menciptakan, memelihara, dan mempertahankan kedamaian dalam interaksi sosial. (Soerjono Soekanto, 2004: 5).

Setiap bangsa manapun pasti menginginkan tecapainya kedamaian dan ketertiban serta keadilan pada masyarakatnya. Bangsa Indonesia 
mempunyai cita-cita yang luhur dalam memberikan kedamaian dan keadilan di masyarakat hal ini diperkuat dengan tercantumnya arah kebijakan dalam bidang hukum terutama pada point (3) sebagaimana termuat di dalam Tap MPR RI: II/MPR/1999; GBHN yaitu penegakan hukum secara konsisten untuk lebih menjamin kepastian hukum, keadilan dan kebenaran, supremasi hukum serta menghargai hak asasi manusia.

Salah satu indikator penegakan hukum adalah manusia sebagai pelaksana termasuk hakim, maka tidak berlebihan jika dikatakan bahwa yang menjadi sorotan utama masyarakat Indonesia adalah hakim dalam arti sempit dan lembaga peradilan dalam arti luas. Sekalipun dalam kenyataan hakim bukan satu-satunya sebagai penentu dalam penegakan hukum sebab dalam penegakan hukum banyak faktor yang mempengaruhi.

(Soerjono Soekanto, 2004: 8) menyebutkan bahwa ada lima faktor yang mempengaruhi penegakan hukum. Faktor-faktor tersebut yang pertama, adalah faktor hukum itu sendiri; kedua, adalah faktor penegakan hukum (dalam hal ini termasuk hakim); ketiga, adalah faktor sarana atau fasilitas yang mendukung penegakan hukum; keempat, adalah faktor masyarakat; dan yang kelima, adalah faktor kebudayaan.

Hakim dalam menjalankan tugasnya sebagaimana dikemukakan oleh Arief Sidharta (Suhrawardi K Lubis, 2002 : 25) adalah memikul tanggung jawab yang besar dan harus mengerti tanggung jawabnya itu, sebab keputusan hakim itu dapat membawa akibat sangat jauh dari kehidupan para 
yustiabel dan atau orang-orang lain yang terkena oleh jangkauan keputusan tersebut. Olehnya itu maka Keputusan hakim yang tidak adil dapat mengakibatkan penderitaan lahir batin yang selalu membekas dalam batin para yustiabel yang bersangkutan sepanjang perjalanan hidupnya.

Para hakim seharusnya lebih terpelajar (bercendikiawan) agar dapat menunjukan keahliannya serta bersikap wajar, dan lebih menghayati serta mengetahui pelbagai faktor yang relevan dengan masalah yang dihadapinya agar tidak sekedar keyakinan. Dengan demikian maka mereka wajib memiliki integrasi dan manfaat. Sedangkan apa yang diemban oleh hakim adalah suatu yang mulia dalam penegakkan hukum, sebab menegakkan hukum berarti menegakkan keadilan maka seorang hakim dituntut untuk lebih memahami profesinya.

Dalam upaya untuk mewujudkan bangsa yang adil dan damai maka diperlukan etika. Baik atau tidaknya suatu bangsa tergantung dari masingmasing individu, jika masyarakat Indonesia itu beretika maka bangsa itu akan damai dan adil. Termasuk profesi dan moral atau antara profesi dan etika. Untuk meningkatkan keprofesionalan tersebut maka diperlukan adanya etika yang harus dipedomani oleh hakim baik di dalam persidangan maupun di luar persidangan.

Oleh karena itu merupakan suatu keharusan sebagaimana yang dikatakan Sahrawardi K Lubis (2002: 4) bahwa etika haruslah dimasukkan dalam pendidikan hokum, hal ini disebabkan belakangan ini terlihat adanya 
gejala penurunan etika di kalangan aparat penegak hukum yang mana hal tersebut aka merugikan bagi pembangunan masyarakat.

Etika profesi merupakan tuntunan bagi seorang hakim dalam menjalankan tugasnya hal itu juga sudah tertuang dalam arah kebijakan bidang hukum pada point (5) sebagaimana yang termuat dalam Tap MPR RI Nomor II/MPR/1999 Tentang Garis-garis Besar Haluan Negara, yaitu meningkatkan integritas moral dan keprofesionalan aparat penegak hukum, termasuk kepolisian negara kepolisian Republik Indonesia untuk menumbuhkan kepercayaan masyarakat dengan meningkatkan kesejahteraan yang efektif.

Menurut Hamzah Ya'kub mengemukakan Etika dalam ilmu yaitu menyelidiki mana yang baik dan mana yang buruk dan memperlihatkan amal perbuatan manusia sejauh yang dapat diketahui oleh akal pikiran.

Dalam bahasa Inggris akhlaq disebut "moral" atau "ethic" dan juga pada bahasa Yunani akhlaq dipakai kata "ethos" ethikos yang kemudian menjadi "ethika" pakai "h" dan etika (tanpa h). kata akhlaq adalah dari bahasa Arab jama' dari kata khuluk artinya perangai atau tabiat. Dalam pengertian Indonesia sehari-hari akhlaq umumnya disamakan dengan budi pekerti atau kesusilaan atau sopan santun. (Ruddin Emang, 1995 : 1).

Etika prosfesi yang tertuang dalam etika hakim itu merupakan aturan, patokan, atau hukum yang harus dipergunakan dan pegang teguh oleh para hakim dalam penghayatan profesi mereka sebagai penegak hukum dan 
keadilan. Hal ini juga akan dipergunakan untuk memakai baik buruknya tindak hakim dalam menjalankan tugasnya bahkan juga menjadi kriteria moral dalam penegak hukum.

Etika di satu sisi sangat berpotensi untuk mewujudkan cita-cita bangsa Indonesia, dengan beretika rakyat akan saling menghargai, membantu, dan menghormati. Etika itu memperhatikan atau mempertimbangkan tingkah laku manusia dalam mengambil keputusan yang baik atau buruk maupun yang benar atau salah.

Orang yang memiliki kesadaran etika dan moral akan senantiasa selalu jujur sekalipun tidak ada orang lain yang melihat, tindakan orang yang bermoral tidak akan menyimpang dan selalu berada pada nilai-nilai etika. Sebab orang yang beretika berdasarkan kesadaran, bukan berdasarkan pada suatu kekuatan dan juga bukan paksaan tetapi berdasarkan kesadaran moral yang timbul dari kesadaran individual bersangkutan dari tuntunan itulah diangkat oleh IKAHI (Ikatan Hakim Indonesia) sebagai etika profesi bagi para hakim.

Beretika dalam menjalankan tugas dan fungsi hakim selalu mendapat sorotan utamanya dalam tingkah laku dan sikap baik dalam tugas maupun luar tugas sebagai kontrol dan berprofesional menjalankan tugasnya, sehingga akan tercipta penegakan hukum yang adil. Etika dan profesionalnya hakim dapat mempengaruhi akhlaq atau moralnya, baik dalam tugas maupun 
di luar tugas, sehingga hati yang luhur, mulia, tanpa, pamrih dan bertanggung jawab tercermin pada tingkah laku seorang hakim.

\section{B. Rumusan Masalah}

Berdasarkan latarbelakang tersebut diatas maka rumusan masalah mengenai peranan hakim dalam menegakan etika profesi hakim tersebut yaitu :

1. Bagaimana fungsi dan peranan etika profesi hukum bagi hakim dalam penegakan hukum?

\section{Tujuan dan kegunaan}

\section{Tujuan.}

Tujuan yang ingin dicapai dalam fokus penelitian ini yaitu :

1. Untuk mengetahui dan memahami fungsi dan peranan etika profesi hukum yang diemban oleh para hakim dalam menegakkan hukum dan mewujudkan keadilan.

\section{Kegunaan}

Manfat yang ingin dicapai dalam penelitian ini yaitu :

1. Segi teoritis, diharapkan dari penelitian ini akan memberikan konstribusi khazanah keilmuan di Indonesia dalam memantapkan eksistensi etika profesi hakim yang sudah terangkum dalam kode etik hakim agar cita-cita negara untuk tegaknya hukum dan keadilan dapat tercapai. 
2. Segi praktis, penelitian ini diharapkan dapat memberikan sumbangan pemikiran kepada para penegak hukum khususnya hakim dalam melaksanakan fungsinya sebagai menegakkan keadilan.

\section{Tinjauan Teoritis.}

Di dalam kamus Besar bahasa Indonesia (Depdiknas,2001:309) menyebutkan bahwa etika adalah ilmu tentang apa yang baik dan apa yang buruk dan tentang hak dan kewajiban moral. Di dalam kamus ini dibedakan antara pengertian etika dan etik. Sedangkan etik adalah asas atau nilai yang berkenaan dengan akhlak, dan nilai mengenai benar dan salah yang dianut oleh suatu golongan atau masyarakat.

Menurut E.Y Kanter (2001:11) bahwa etika merupakan ilmu dan termsasuk cabang filsafat yang paling tua sejak zaman Yunani kuno. Etika adalah refleksi kritis, metodis, dan sistematis tentang tingkah laku manusia dari sudut baik dan buruk.

Purwoto S. Gandasubrata mengartikan etik (etika) dalam (Mahkamah Agung : $2004: 2$ ) adalah merupakan falsafah moral untuk mendapat petunjuk tentang perilaku yang baik, berupa nilai-nilai luhur dan aturan-aturan pergaulan yang baik, dalam hidup bermasyarakat dan kehidupan pribadi.

Encyclopedia Britanica (Abduddin Nata, 1996:88) adalah etika dinyatakan sebagai filsafat moral, yaitu studi yang sistematik mengenai sifat dasar dari konsep-konsep nilai baik, buruk, harus, benar salah dan sebagainya. 
James J. Spillane (Suharwadi K. Lubis, 2002 : 1) mengungkapkan bahwa etika atau ethics memperhatikan atau mempertimbangkan tingkah laku manusia dalam pengambilan keputusan moral. Etika mengarahkan atau menghubungkan penggunaan akal budi individual dengan objektivitas untuk menentukan "kebenaran" atau "kesalahan" dan tingkah laku seseorang terhadap orang lain.

Menurut Frankena (Abuddin Nata, 1996:86) mengemukakan bahwa etika adalah sebagai cabang filsafat, yaitu filsafat moral atau pemikiran filsafat tentang moralitas, problem moral dan pertimbangan moral.

Menurut Abdullas Salim (Suhrawardi K. Lubis, 2002:3) bahwa dalam Islam etika adalah merupakan bagian dari akhlak, karena akhlak bukanlah sekedar menyangkut perilaku manusia yang bersifat perbuatan lahiriyah saja akan tetapi mencakup hal-hal yang lebih luas yaitu meliputi bidang akidah, ibadah dan syari'ah. Karena akhlak Islam cakupannya sangat luas yaitu mencakup etos, etis, moral dan estetika sebab :

1. Etos; yang mengatur hubungan seorang dengan khaliqnya, alma'bud bi haq serta kelengkapan uluhiyah dan rububiyyah, seperti terhadap Rasul-rasul Allah, Kitab-Nya, dan sebagainya.

2. Etis; yang mengatur sikap seseorang terhadap dirinya dan terhadap sesamanya dalam kegiatan kehidupan sehari-harinya.

3. Moral; yang mengatur hubungan dengan sesamanya, tetapi berlainan jenis atau menyangkut kehormatan tiap pribadi. 
4. Estetika; rasa keindahan yang mendorong seseorang untuk meningkatkan keadaan dirinya serta lingkungannya agar lebih indah dan menuju kesempurnaan.

Menurut Farid Ma'ruf (1995:5) bahwa pokok persoalan etika adalah segala perbuatan manusia yang timbul dari orang yang melakukan dengan sengaja, dan mengetahui waktu melakukan apa yang di perbuat. Inilah yang dapat di beri hukum "baik dan buruk", perbuatannya.

Sedangkan menurut Asmaran AS (1992:6-7) mengemukakan bahwa etika ialah studi tentang tingkah laku manusia, tidak hanya menentukan kebenarannya sebagaimana adanya, tetapi juga menyelidiki manfaat atau kebaikan dari seluruh tingkah laku manusia.

Hamzah Ya’kub (1983 : 13) mengemukakan bahwa etika ialah ilmu yang menyelidiki mana yang baik dan mana yang buruk memperlihatkan amal perbuatan manusia sejauh yang dapat diketahui oleh akal pikiran.

Jadi tugas utama etika ialah penyelidikan terahadap apa yang harus dilakukan manusia. Dalam etika, berbicara, dan dianalisis tema-tema sentral seperti hati nurani, kebebasan, tanggung jawab, norma, hak, kewajiban, dan keutamaan. Etika bergerak di bidang intelektual, tetapi objek langsung berkaitan dengan kehidupan praktis. (E.Y Kanter, 2001:11).

Antara etika dan moral memiliki objek yang sama, yaitu sama-sama membahas tentang perbuatan manusia untuk selanjutnya ditentukan 
posisinya apakah baik atau buruk selain itu juga etika dan moral berbicara tentang nilai.

Nilai menurut E.Y Kanter (2001 :5) bahwa suatu perbuatan akan nampak jelas manakala perbuatan itu sendiri sudah dilakukan. Itu berarti nilai merupakan apresiasi atas fakta atau peristiwa yang terjadi. Di sini fakta mendahului nilai, karena itu ada tiga ciri nilai. Yaitu, 1) Nilai berkaitan dengan subyek yang menilai, 2) Nilai terjadi dalam praktis hidup ketika subjek ingin membuat sesuatu, dan 3) Nilai merupakan sifat-sifat yang ditambahkan oleh subjek dan sifat-sifat yang dimiliki objek dari dirinya sendiri objek tidak memiliki nilai.

Namun demikian dalam beberapa hal etika dan moral memiliki perbedaan :

1. Etika adalah untuk menentukan nilai perbuatan manusia baik atau buruk menggunakan tolak ukur akal pikiran atau rasio, sedangkan pada moral tolok ukur yang digunakan adalah norma-norma yang tumbuh dan berkembang langsung di masyarakat.

2. Kesadaran moral dapat juga berwujud rasional dan obyektif, yaitu suatu perbuatan umum yang dapat diterima di masyarakat. Misalnya manusia bebas dari paksaan dan tekanan, tidak mencari keuntungan sendiri, tidak berpihak, bersedia untuk bertindak sesuai dengan kaidah yang berlaku secara umum, pengetahuan yang berdasarkan informasi yang obyektif. 
3. Kesadaran moral dapat pula muncul dalam bentuk kebebasan. Atas kesadaran moralnya seseorang bebas untuk mentaatinya. Bebas dalam menentukan perilakunya dan di dalam penentuan itu sekaligus terpampang nilai manusia itu sendiri. (Abuddin Nata,1996:91-93).

Manusia sudah pasti mempunyai moral, akan tetapi belum tentu setiap manusia memiliki pemikiran secara kritis tentang moralnya. Pemikiran yang kritis tentang moral inilah yang disebut etika. (Darji Darmodiharjo, 1996 : 33).

Dari berbagai pendapat di atas dapat diambil garis besar bahwa etika itu suatu ilmu yang menjelaskan arti baik dan buruk atau benar dan salah, menerangkan apa yang harus dilakukan manusia terhadap sesamanya, menyatakan tujuan yang harus dituju oleh manusia di dalam perbuatan mereka dan menunjukkan jalan untuk melakukan apa yang harus dilakukan manusia dalam melakukan interaksi baik sesama manusia maupun alam disekitarnya.

Etika menyelidiki segala perbuatan manusia kemudian menetapkan hukum baik atau buruk perbuatannya, akan tetapi bukanlah segala perbuatan manusia itu dapat diberi hukum. Pelanggaran terhadap hukum pasti akan dihukum atau dikenakan sanksi sesuai dengan perbuatannya serta aturan yang berlaku, sedangkan terhadap etika lebih mengedepankan hati nurani manusia, menimbulkan suatu kesadaran terhadap masyarakat bahwa apabila seseorang dikenakan sanksi belum tentu orang itu dapat digolongkan sebagai orang yang kurang baik. 
Sedangkan pengertian profesi adalah bidang pekerjaan yang ditandai dengan pendidikan keahlian, keterampilant tertentu, dan sebagainya. Sedangkan Profesional adalah sesuatu yang bersangkutan dengan profesi yaitu sesuatu yang memerlukan kepandaian khusus untuk menjalankannya. (Depdiknas, 2001:397).

Menurut Achmad Ali (1998:335) yang dimaksud dengan profesi didalamnya terdapat unsur-unsur yaitu :

1. Merupakan pekerjaan atau lapangan kerja yang hanya mungkin dicapai dengan pendidikan atau latihan khusus.

2. Keahlian berdasarkan kemampuan teoritis namun dalam penerapannya tergantung pada kemampuan person.

3. Mendapat pengakuan dari masyarakat.

4. Kemampuan itu ditunjukkan untuk sebagai pelayanan umum.

5. Adanya organisasi atau asosiasi profesi dengan etika profesi yang lain.

Profesi adalah suatu gelar atau jabatan di mana orang yang menyandangnya memiliki pengetahuan khusus yang diperoleh melalui training atau pengalaman lain atau diperoleh melalui keduanya sehingga penyandang profesi dapat membimbing atau memberi nasehat serta saran dan juga melayani orang lain dalam bidangnya sendiri. (E. Y Kante 2001:63).

Selain itu pula adapun ciri-ciri profesi menurut Budi Santoso dalam kansil (1997:4) antara lain : 
1. Suatu bidang yang telah terorganisir dari jenis intelektual yang terus menerus dan berkembang serta diperluas.

2. Suatu teknis intelektual

3. Penerapan praktis dari teknis intelektual pada urutan praktis

4. Suatu periode panjang untuk pelatihan dan sertivikasi

5. Beberapa pernyataan dan standar tentang etika yang dapat diselenggarakan

6. Kemampuan memberi kepemimpinan pada profesi sendiri

7. Asosiasi dan anggota profesi yang menjadi suatu kelompok yang akrab dengan kualitas komunikasi antar anggota

8. Pengakuan sebagai professional terhadap penggunaan yang bertanggung jawab dari pekerjaan profesi

9. Hubungan erat dengan profesi lain.

Menurut Brandeis dalam Darji darmodiharjo (1999:264) bahwa dikatakan sebagai suatui profesi, maka pekerjaan itu harus mencerminkan adanya dukungan berupa :

1. Ciri-ciri pengetahuan (intelektual character)

2. Diabadikan untuk kepentingan umum

3. Keberhasilan pekerjaan tersebut tidak berdasarkan pada keberhasilan finansial 
4. Didukung dengan adanya organisasi profesi dengan menentukan ketentuan berupa kode etik, serta bertanggung jawab memajukan dan menyebarkan profesi yang bersangkutan

5. Ditentukan oleh standar kualifikasi profesi dan ditambahkan dengan adanya penghargaan masyarakat.

Dari berbagai pendapat di atas dapat disimpulkan bahwa profesi adalah suatu keahlian yang dimiliki oleh seseorang atau sekelompok orang melalui pendidikan atau latihan khusus yang bermanfaat bagi dirinya sendiri maupun masyarakat luas disertai dengan jiwa bertanggung jawab dan tanpa pamrih.

Sementara yang dimaksudkan dengan etika profesi adalah bagian dari etika sosial, yaitu filsafat atau pemikiran kritis rasional tentang kewajiban dan tanggung jawab manusia sebagi anggota umat manusia. (Frans Magnis Suseno, 1999:9).

Etika profesi adalah norma-norma, syarat-syarat, dan ketentuanketentuan yang harus dipenuhi oleh sekelompok orang yang disebut kalangan professional. (E. Y. Kanter, 2001:61).

Etika profesi memiliki kaidah-kaidah pokok :

1. Profesi harus dipandang sebagai pelayanan dan oleh Karena itu sifat "tanpa pamrih" menjadi ciri khas dalam mengembangkan profesi

2. Pelayanan professional dalam mendahulukan kepentingan pencari keadilan mengacu pada nilai-nilai luhur 
3. Pengembangan dalam pelayanan berlangsung secara sehat, sehingga dapat menjamin mutu dan peningkatan mutu pengembang profesi. (Wildan Suyuthi, 2004:28).

Sebagai penegak hukum terutama hakim yang sangat berperan penting di dalam suatu persidangan hendaknya berpegang teguh pada peraturanperaturan, nilai-nilai, moral dan kaedah-kaedah, kode etik hakim, sehingga tidak terjadi penyimpangan yang dapat merusak citra hakim.

Kode etik hakim (Wildan Suyuthi, 2004:30) yaitu :

1. Mempersamakan kedudukan semua pihak (para pihak) dalam Majelis, pandangan dan putusan sehingga orang mulia tidak mengharapkan kecurangan hakim, orang lemah takkan berputus asa dalam mencari keadilan.

2. Perdamaian hendaklah selalu diusahakan di antara para bersengketa kecuali perdamaian yang menghalalakan yang haram atau mengharamkan yang halal.

Maksud dan tujuan hadirnya kode etik hakim atau profesi hakim adalah sebagai berikut:

1. Sebagai alat yaitu untuk melakukan pembinaan dan pembentukan karakter hakim serta untuk pengawasan tingkah laku hakim.

2. Sebagai sarana kontrol sosial, mencegah campur tangan ekstra judicial serta sebagai sarana pencegah timbulnya kesalahpahaman antara sesama anggota dan antara anggota dengan masyarakat. 
3. Untuk lebih memberikan jaminan bagi peningkatan moralitas hakim dan kemandirian fungsional bagi hakim.

4. Untuk menumbuhkan kepercayaan masyarakat pada lembaga peradilan. (Wildan Suyuthi,2004 : 32-34).

Etika profesi merupakan suatu kumpulan norma, kaidah yang memiliki nilai moral serta ketentuan-ketentuan yang harus dipenuhi oleh sekelompok orang yang disebut professional dalam hal ini hakim yang memiliki cita-cita yang luhur demi kepentingan orang banyak tanpa melupakan kepentingan dirinya sendiri disertai dengan tenggung jawab.

\section{a. Tugas dan Fungsi Hakim}

Hakim sebagai pelaksana kekuasaan kehakiman keberadaannya telah ditentukan dalam Undang-Undang Dasar Negara Republik Indonesia Tahun 1945 dan perubahannya yaitu pada Bad IX; Tentang Kekuasaan Kehakiman, pasal 24 ayat (2) yang bunyinya :

"Kekuasaan kehakiman dilakukan oleh sebuah Mahkmah Agung dan badan peradilan yang berada di bawahnya dalam lingkungan peradilan umum, lingkungan peradilan agama, lingkungan peradilan militer, lingkungan peradilan tata usaha negara, dan oleh sebuah Mahkamah konstitusi."

Tugas hakim sebagai penegak hukum dan keadilan telah dirumuskan dalam Undang-undang Nomor 4 Tahun 2004 Tntang Kekuasaan Kehakiman pasal (1) yang isinya sebagai berikut :

"Kekuasaan Kehakiman adalah kekuasaan negara yang merdeka untuk menyelenggarakan peradilan guna menegakkan hukum dan 
keadilan berdasarkan Pancasila demi terselenggaranya negara hukum Republik Indonesia."

Demi tegaknya hukum dan keadilan maka tugas pokok hakim disebutkan lebih lanjut dalam pasal-pasal sebagai berikut :

Pasal 2 ayat (1) :

Penyelenggaraan kekuasaan kehakiman tercantum dalam pasal (1) diserahkan kepada badan peradilan dan ditetapkan dengan Undangundang, dengan tugas pokok untuk menerima, memeriksa dan mengadili serta menyelesaikan setiap perkara yang diajukan kepadanya".

Hukum yang berasal dari "kata hakama" yang berarti meninjau dan menetapkan sesuatu hal dengan adil dengan tidak berat sebelah, maka adil dan keadilan merupakan tujuan dan inti dari pada hukum. Adil mengandung pengertian meletakkan sesuatu pada tempatnya, untuk menegakkan hukum dan keadilan itulah dibebankan pada pundak hakim sebagai konsekwensi dari negara hukum. (Wildan Suyuthi, 2004 : 25).

Adil menurut kamus bahasa Indonesia adil diartikan tidak berat sebelah (tidak memihak), tidak sewenag-wenang. Selanjutnya kata adil digunakan untuk kegiatan yang lebih khusus. Kata adil dihubungkan dengan tugas seorang hakim yang memutuskan perkara (Abuddin Nata, 2002:235).

Dalam melaksanakan tugasnya hakim kadang-kadang merupakan corong undang-undang dalam kasus hukum telah jelas menentukan sehingga hakim tinggal menerapkannya, pada saat yang lain hakim harus menafsirkan undang-undang yakni apabila dalam kasus yang hukumnya tidak tahu atau 
belum jelas sehingga memerlukan penafsiran dengan cara metode penafsiran yang dikenal dalam ilmu hukum. Pada saat yang sama juga dituntut untuk menemukan hukumnya di saat undang-undang belum mengatur kasus tersebut (rechtvinding), karena hakim tidak boleh menolak untuk mengadili suatu perkara yang diajukan dengan alasan bahwa hukum itu belum ada atau kurang jelas, akan tetapi hakim harus memeriksa dan mengadilinya.

Hakim sebagai penegak hukum dan keadilan wajib menggali, mengikuti dan memahami nilai-nilai hukum yang hidup dalam masyarakat dan dapat memberikan putusan yang sesuai dengan hukum dan rasa keadilan masyarakat. Karena hakim yang tidak memahami profesinya dan tugasnya dalam artian kurang pemahamnnya terhadap profesinya dengan ilmunya membuat setiap keputusanya tidak sesuai dengan kaidah-kaidah hukum maka perlu di pertanyakan etika profesinya.

Tugas hakim untuk menentukan hukum dan keadilan dalam masyarakat sangat lah berat dan mulia. Berat karena sebagai manusia biasa yang penuh dengan segala kekurangannya tapi diberi hak oleh negara untuk dan atas nama Tuhan yang Maha Esa untuk menentukan salah tidaknya, benar tidaknya tindakan seseorang. Bahkan dalam perkara pidana menyangkut mati hidupnya seseorang, profesi hakim sangat luhur dan mulia karena dengan keputusannya seorang hakim mampu menampakkan cahaya kebenaran dan keadilan yang diharapkan masyarakat. 
Oleh karena itu kekuasaan yang begitu besar itulah maka hakim harus dituntut dan diimbangi dengan sikap yang penuh rasa tanggung jawab pada hati nurani, serta nilai-nilai etik terhadap profesinya. Tidak berbeda dengan semua orang, hakim adalah manusia biasa, maka dalam memberikan putusannya untuk mencari kebenaran, tidaklah berarti bahwa apa yang telah diyakininya itu telah benar secara mutlak. hal ini berarti, bahwa tanggung jawab hakim dalam mengembangkan tugasnya besar sekali, karena di samping harus bertanggunggjawab kepada masyarakat dan negara juga terhadap Tuhan.

Hakim dalam menetapkan sesuatu keputusan benar atau tidaknya terdakwa dan hukuman apa yang sesuai dengan perbuatan haruslah sesuai dengan ketentuan perundang-undangan yang berlaku selain itu pula apakah hukuman dan letak keadilan bagi sengketa atau pelanggran hokum telah sesuain atau belum.

Sebagaimana penjelasan UUD 45 menyebutkan bahwa Republik Indonesia adalah negara hukum dan konsekwensinya ditentukan kekuasaan Kehakiman yang merdeka, terlepas dari pengaruh pemerintah dan karenanya harus ada jaminan tentang kedudukan hakim.

\section{b. Etika Profesi dan Kode Etik Hakim}

Dalam bahasan di atas telah disebutkan bahwa etika adalah kumpulan asas atau nilai moral. 
Menurut K. Bertens (2002:141) bahwa nilai sekurang-kurangnya memiliki tiga ciri berikut ini :

1. Nilai berkaitan dengan subyek, kalau tidak ada subyek yang menilai maka tidak ada nilai juga.

2. Nilai tampil dalam suatu konteks praktis, di mana subyek ingin membuat sesuatu. Dalam pendekan yang semata-mata teoritis tidak akan ada nilai.

3. Nilai-nilai menyangkut sifat-sifat yang ditambah oleh subyek pada sifat-sifat yang dimiliki oleh obyek.

Sedangkan nilai moral tidak merupakan suatu kategori nilai tersendiri disamping kategori-kategori nilai tang lain. Nilai moral tidak terpisah dari nilainilai jenis lainnya. Setiap nilai dapat memperoleh suatu bobot moral bila diikut sertakan dalam tingkah laku moral, misalnya kejujuran merupakan suatu nilai moral namun kejujuran itu kosong bila tidak diterapkan dengan perilaku (hakim).

Hakim dalam melaksanakan profesinya dituntut kejelasan dan kekuatan moral yang tinggi. (E. Sumaryono; 1995 : 165) bahwa ada tiga ciri kepribadian moral yang dituntut dari para penyandang atau pemegang profesi luhur ini yaitu :

1. Berani berbuat tekad untuk memenuhi tuntunan profesi

2. Sadar akan kewajiban yang harus dipenuhi selama menjalankan tugas profesionalnya. 
3. Memiliki idealisme sebagai perwujudan masing-masing organisasi profesionalnya.

Artinya setiap hakim dalam kedudukan dan fungsinya masing-masing dituntut untuk bertindak dengan tekat dan semangat yang sesuai dengan citacita dan tuntutan profesinya. la harus memiliki kepribadian moral yang kuat, ia bukanlah orang yang hanya mengikuti perasaan dan emosinya saja namun ia harus bebas dari rasa malu, malas, takut bertindak bahkan harus bebas dari perasaan sentimen ataupun kebencian, begitu juga dengan kesadaran akan kewajiban idealisme para hakim yaitu kesadaran atas profesinya bukan karen terpaksa demi ketentuan atas peraturan itu sendiri serta sungguhsungguh dan tanpa pamrih atau melayani masyarakat menurut jalur-jalur yang digariskan dalam nilai-nilai dan kode etik profesinya.

Kepribadian moral yang kuat telah dikemukakan oleh Franz Magnis Suseno (E. Sumaryono, 1995:65-170) yaitu ada lima sikap yang dipandang mendasari kepribadian sebagai berikut :

1. Kejujuran

2. Nilai-nilai autentik

3. Kesediaan akan bertanggung jawab

4. Kemandirian moral

5. Keberanian moral

6. Kerendahan hati 


\section{Metode Pendekatan}

Pendekatan penelitian ini dilakukan dengan kajian secara yuridis penelaahan literatur hukum, dan peraturan perundang-undangan yang ada hubungannya dengan kajian ini lalu kemudian dikombinasikan. Berdasarkan latar belakang masalah guna dapat memperoleh jawaban atas pokok permasalahan di atas, maka digunakan metode penelitian hukum Normatif yang diarahkan untuk mengetahui dengan mengkaji undang-undang yang berkaitan dengan kajian ini yaitu Undang-Undang Dasar Negara Republik Indonesia Tahun 1945 dan perubahannya. Undang-Undang Nomor 4 Tahun 2004, tentang kekuasaan kehakiman serta Undang-undang Nomor 5 Tahun 2004, tentang Peradilan Umum.

Pendekatan ini untuk mengetahui sejauh mana peranan etika profesi hukum yang dijalankan oleh para hakim dalam mewujudkan keadilan dan mengetahui kedudukan etika profesi hukum bagi hakim.

\section{A. Bahan Hukum}

Untuk memperoleh bahan yang diperlukan maka dalam penelitian ini bahan hukum bersumber :

1. Bahan Hukum Primer yaitu bahan-bahan hukum yang mengikat, dan terdiri dari:

a. Peraturan dasar

b. Peraturan perundang-undangan 
c. Bahan hukum yang tidak dikodifikasi

d. Yurispudensi

2. Bahan Hukum Sekunder, yang memberikan penjelasan mengenai bahan hukum primer, seperti hasil-hasil penelitian dan hasil karya dari kalangan hukum.

\section{B. Tehnik Pengumpulan Bahan Hukum}

Bahan Hukum yang diperoleh dan memiliki relevan dengan pokok permasalahan yang di inventarisasi dan mempelajari peraturan perundangundangan dan hasil karya dari kalangan hukum yang relevan dengan permasalahan yang akan dibahas dalam penelitian ini.

\section{Analisis}

Bahan hukum yang telah diperoleh dalam penelitian ini diseleksi berdasarkan fasilitasnya yang selanjutnya dianlisis secara kualitatif. Analisis kualitatif ini dilakukan berdasarkan tipe dalam penelitian ini yaitu tipe penelitian hukum normatif.

Bahan hukum yang sifatnya literatur-literatur, perundang-undangan dianalisis secara kualitatif dengan mengungkapkan fungsi dan peranan etika profesi hukum bagi hakim dalam mewujudkan keadilan. 


\section{HASIL PENELITIAN DAN PEMBAHASAN}

\section{A. Fungsi dan Peranan Etika Profesi Hukum bagi Hakim dalam Penegakan Hukum}

Dinamika kehidupan sehari-hari sudah menjadi fakta bahwa sering terjadi konflik antara individu atau kelompok dengan individu atau kelompok lainnya. Konflik yang terjadi tidak dapat diselesaikan oleh para pihak yang terkait dalam konflik. Untuk dapat menyelesaikan konflik, sering kali ada campur tangan institusi khusus yang memberikan penyelesaian imparsial (secara tidak memihak). Penyelesaian itu didasarkan kepada patokanpatokan yang berlaku secara obyektif. Fungsi ini lazimnya dijalankan oleh suatu lembaga yang disebut lembaga peradilan yang berwenang melakukan pemeriksaan, penilaian, dan memberikan keputusan terhadap konflik. Wewenang yang sedemikian itulah yang disebut dengan kekuasaan kehakiman yang di dalam praktiknya dilaksanakan oleh hakim.

Agar dapat menyelesaikan masalah atau konflik yang dihadapkan kepadanya secara imparsial berdasarkan hukum yang berlaku, maka dalam proses pengambilan keputusan, hakim hanya terikat pada fakta-fakta yang relevan dan kaidah hukum yang menjadi landasan yuridis keputusannya. Akan tetapi penentuan fakta-fakta mana yang termasuk fakta-fakta yang relevan dan pilihan kaidah hukum yang mana akan dijadikan landasan untuk

menyelesaikan kasus yang dihadapinya dan diputuskan oleh hakim yang bersangkutan itu sendiri. Hal ini berarti hakim memiliki kekuasaan, 
sebagaimana ditegaskan oleh Mochtar Kusuma Atmadja (Suhrawardi K. Lubis, 2002 : 25) bahwa "kekuasaan yang besar terhadap para pihak (yustiabel) berkenaan dengan masalah atau konflik yang dihadapkan kepada hakim atau para hakim tersebut".

Dalam drama Cade'S Rebellion, Shakespreare (E.Y. Kanter, 2001 : 110) mengatakan bahwa Bunuhlah semua pengacara (profesional hukum) kalau ingin mengubah negara demokratis menjadi negara totaliter (absolut), atau jika kita ingin negara ini penuh korupsi, bobrok, rusak, dan hancur karena main kuasa dan main hakim sendiri".

Pernyataan di atas menunjukkan hakikat para penegak hukum, yaitu hakim, jaksa, pengacara, notaris, dan polisi adalah pembela kebenaran dan keadilan. Para pemangku profesi hukum bertugas memberikan kepastian hukum kepada pencari kebenaran dan keadilan. Mereka memberikan bantuan hukum secara profesional kepada klien berdasarkan hukum, keadilan, dan kebenaran. Mereka harus melaksanakan dengan itikad baik dan ikhlas, karena profesi hukum merupakan profesi terhormat dan luhur.

Para hakim dalam menjalankan tugas sepenuhnya memikul tanggung jawab yang besar dan harus menyadari tanggung jawabnya itu, sebab keputusan hakim dapat membawa akibat yang sangat jauh pada kehidupan para pihak yang terkena jangkauan keputusan hakim. Keputusan hakim yang tidak adil bahkan dapat mengakibatkan penderitaan lahir dan batin yang 
dapat membekas dalam batin para pihak yang terlibat dalam konflik dan penyelesaiannya dilaksanakan oleh hakim sebagai penegak hukum.

Hakim adalah pejabat yang melaksanakan tugas kekuasaan kehakiman (Pasal 11 Undang-Undang nomor 7 tahun 1989, pasal 12 ayat (1) Undang-Undang nomor 5 tahun 1986), yakni Pejabat Peradilan yang diberi wewenang oleh undang-undang untuk mengadili (Pasal 1 Undang-Undang nomor 8 tahun 1981). Istilah pejabat membawa konsekuensi yang berat, oleh karena kewenangan dan tanggung jawabnya terumuskan dalam rangkaian tugas, kewajiban, sifat dan sikap tertentu yaitu penegak hukum dan keadilan.

Dalam melaksanakan tugasnya, hakim harus bersikap adil, obyektif dan tidak memihak sesuai dengan ketentuan dalam hukum acara yang memberikan jaminan yang obyektif bagi perlakuan yang adil dalam pemeriksaan di muka sidang demi terselenggaranya suatu "fair trial".

Profesi hakim sebagai salah satu bentuk dari profesi hukum sering digambarkan sebagai pemberi keadilan. Istilah etika senantiasa dikaitkan dengan tindakan yang baik atau etika berhubungan dengan tingkah laku manusia dalam pengambilan keputusan moral, di mana profesi merupakan pekerjaan, sedangkan hakim merupakan suatu profesi, karena memenuhi kriteria-kriteria, pekerjaan tetap di bidang tertentu, berdasarkan keahlian tertentu, dilakukan secara bertanggung jawab, dan memperoleh penghasilan.

Setiap Profesi hakim mempunyai kedudukan atau tugas khusus karena fungsinya memerlukan persyaratan-persyaratan yang lebih berat. 
Hukum mengatur tindakan-tindakan manusia yang nyata dan harus mendasarkan pada peraturannya yaitu pembuktian dan sanksinya pada tindakan-tindakan nyata. Perbuatan-perbuatan merugikan, baik itu dilakukan oleh penegak hukum (hakim) tidak selalu merupakan tindakan yang nyata atau kalaupun nyata tidaklah mudah kualifikasi dan pembuktiannya sebagai perbuatan atau tindakan yang melanggar hukum. Oleh karena itu, persoalan perlindungan kepentingan umum dalam hal ini pihak-pihak yang berperkara untuk memperoleh penegakan hukum sebagaimana mestinya dan perorangan yang mencari keadilan selain harus diamankan melalui pengaturan hukum harus dikembalikan pada aturan hidup manusia yang tidak tertulis yang bersumber pada hati nuraninya sendiri yaitu etika, moral, dan agama. Dengan demikian, pada hakikatnya etika profesi hukum merupakan suatu bentuk penuangan kongkrit dari para aturan etika, moral, dan agama.

Etika profesi hukum sangat penting bagi setiap penegak hukum, tidak terkecuali hakim. Etika profesi hukum mempunyai fungsi dan peranan tidak hanya mengajar apa yang diketahui atau apa yang harus dilakukan oleh seorang penegak hukum akan tetapi bagaimana yang seharusnya seorang hakim yang berkepribadian baik. (Wildan Suyuthi). Hal ini berarti bahwa fungsi dan peranan etika profesi hukum bagi hakim sebagai penegak hukum adalah sebagai pedoman oleh setiap hakim dalam melaksanakan tugas profesi sebagai hakim. Hal ini dituangkan dalam Kode Etik Profesi Hukum, Bab I, Pasal 1 ayat (2) (Wildan Suyuthi) bahwa "pedoman tingka laku bagi 
hakim ialah penjabaran dari kode etik profesi hakim yang menjadi pedoman bagi hakim Indonesia, baik dalam menjalankan tugas profesinya untuk mewujudkan keadilan dan kebenaran maupun dalam pergaulan sebagai anggota masyarakat yang harus dapat memberikan contoh dan suri teladan dalam kepatuhan dan ketaatan kepada hukum.

Perkataan hukum yang berasal dari hakama yang berarti meninjau dan menetapkan sesuatu hal dengan adil dengan tidak berat sebelah, maka adil dan keadilan merupakan tujuan dan inti dari pada hukum. (Wildan Suyuthi). Adil mengandung pengertian meletakkan sesuatu pada tempatnya, untuk menegakkan hukum dan keadilan itulah dibebankan kepada pundak hakim sebagai konsekuensi dari negara hukum, sebagaimana penjelasan UndangUndang Dasar 1945 menyebutkan bahwa Negara Republik Indonesia adalah negara hukum dan konsekuensinya ditentukan kekuasaan kehakiman yang merdeka, terlepas dari pengaruh kekuasaan pemerintah.

Dengan putusannya, hakim menetapkan apa hukum dan keadilannya dalam sengketa atau pelanggaran hukum. Dengan demikian, tugas hakim dalam penegakan hukum bersifat repressif. Menurut Wildan Suyuthi dalam artinya "menentukan hukum dan keadilan itu setelah terjadinya kasus-kasus yang kongkrit yang pada gilirannya dengan putusannya hakim menciptakan salah satu sumber hukum".

Tugas hakim untuk menentukan hukum dan keadilan dalam masyarakat adalah berat tetaip mulia. Berat karena sebagai manusia biasa 
yang penuh dengan segala kekurangannya tapi diberi hak istimewa (previlege) oleh negara dan atas nama Tuhan Yang Maha Esa untuk menentukan salah tidaknya, benar tidaknya tindakan seseorang, bahkan dalam perkara pidana mati hidupnya sesorang. Luhur dan mulia karena dengan keputusannya seorang hakim mampu menampakkan cahaya kebenaran dan keadilan yang diharapkan masyarakat. Oleh karena kekuasaan yang begitu besar yang melekat pada hakim, maka mereka dituntut dan di imbangi dengan sikap yang penuh rasa tanggung jawab kepada hati nurani, nilai-nilai etik masyarakat dan Tuhan karena hakim telah menjadi profesi, maka setiap hakim harus melaksanakan etika profesi hukum secara bertanggung jawab. 


\section{KESIMPULAN DAN SARAN}

\section{A. Kesimpulan}

Berdasarkan hasil penulisan mengenai fungsi dan peranan etika profesi hukum bagi hakim dalam hal peengakan hukum, disimpulkan sebagai berikut:

1. Fungsi dan peranan etika profesi hukum bagi hakim dalam hal penegakan hukum adalah sebagai pedoman oleh setiap hakim dalam melaksanakan tugas profesi sebagai hakim yang tidak hanya mengajar apa yang diketahui atau apa yang harus dilakukan oleh seorang hakim sebagai penegak hukum dan seharusnya seorang hakim yang berkepribadian baik dalam menegakkan hukum dengan memberi kepastian hukum, pemanfaatan, dan keadilan bagi para pihak yang berperkara di pengadilan.

2. Sikap hakim dalam mengimplementasikan etika profesi hukum melalui sikapnya dalam tugas maupun di luar tugas. Sikap hakim sebiagai profesi hukum dalam tugas meliputi, baretika dalam persidangan, beretika terhadap sesama rekan, beretika terhadap bawahan atau pegawai, beretika terhadap atasan, beretika terhadap sesama rekan hakim, dan terhadap instansi lain, sedangkan sikap hakim di luar tugas meliputi sikap pribadi hakim sendiri, seperti beretika terhadap masyarakat, dan beretika dalam keluarga serta beretika dalam kehidupan sehari-hari. 


\section{B. Saran}

Mengacu kepada kesimpulan penulisan di atas, maka diajukan saransaran yaitu :

1. Mahkamah Agung, hendaknya melakukan pembinaan hakim yang secara terus-menerus dalam pembinaan etika atau moral dalam meningkatkan citra lembaga peradilan di mata masyarakat.

2. Hakim, hendaknya benar-benar memahami etika profesi hakim dalam melaksanakan tugas sebagai penegak hukum sehingga dalam melaksanakan profesinya benar-benar memiliki sikap yang sesuai dengan etika profesi yang dijalankan dalam penegakan hukum, baik menyangkut kepastian hukum, kemanfaatan, dan keadilan bagi masyarakat. 


\section{DAFTAR PUSTAKA}

Abd. Kadir, 1997, Etika Profesi Hukum, PT. Citra Aditya Bakti, Bandung. Abd. Sani, 1977, Hakim dan Keadilan Hukum, Cetakan I, Bulan Bintang, Jakarta.

Achmad Ali, 1998, Menjelajah Kajian Empiris Hukum, Yarsif Watampone, Jakarta.

, 1999, Pengadilan dan Masyarakat, Hasanuddin University

Press, Ujung Pandang. , 2002, Menguak Tabir Hukum, Toko Gunung Agung, Jakarta.

Anonim, 2001, Kamus Besar Bahasa Indonesia, Cetakan I, Edisi III Depdiknas, Balai Pustaka, Jakarta.

As'ad Sungguh, 2000, 25 Etika Profesi, Sinar Grafika, Jakarta.

Bambang Sunggono, 2001, Metodologi Penelitian Hukum, Raja Grafindo

Persada, Jakarta.

Bimar Siregar, 1995, Hukum Hakim dan Keadilan Tuhan Kumpulan Catatan Hukum dan Peradilan Di Indonesia, Cetakan III, Jakarta.

E. Sumaryono, 1995, Etika Profesi Hukum, Kanisius, Jakarta.

E.Y. Kanter, 2001, Etika Profesi Hukum sebuah Pendekatan Sosio-Religius, Storia Grafika, Jakarta.

Bernard Arief Sidharta, 2000, Refleksi Tentang Struktur Ilmu Hukum, Cetakan II, PT. Mandar Maju, Bandung.

K. Bertens, 2002, Etika, Gramedia Pustaka Utama, Jakarta.

Mahkamah Agung, 2004, Buku Kerja.

Qemar Seno Adji, 1995, Etika Profesional dan Hukum Profesi Advokat, Cetakan I, Erlangga, Jakarta. 
Rifyal Ka'bah, 2002, Integritas Moral Hakim, Jurnal Pusdiklat, Volume II Nomor 4, Pusdiklat MA-RI, Jakarta.

Soerjono Soekanto, 2002, Faktor-Faktor Yang Mempengaruhi Penegakan Hukum, Raja Grafindo Persada, Jakarta.

Suhrawardi K. Lubis, 2000, Etika Profesi Hukum, Sinar Grafika, Jakarta.

Sudikno Metokusumo, 1999, Mengenal Hukum, Edisi Ke empat, Cetakan II, Liberty, Yogyakarta.

Wildan Suyuthi, 2004, Pedoman Perilaku Hakim (Code Of Conduct) Kode Etik Hakim dan Makalah Berkaitan, Mahkamah Agung RI, Jakarta.

Peraturan Perundang-undangan :

Undang-Undang Dasar Negara Republik Indonesia tahun 1945 dan Perubahannya.

Undang-undang Nomor 7 Tahun 1989, tentang Peradilan Agama.

Tap MPR RI Nomor II/ MPR/ 1999, tentang Garis-Garis Besar Haluan Negara.

Undang-undang Nomor 4 Tahun 2004, tentang kekuasaan Kehakiman. Undang-undang Nomor 5 Tahun 2004, tentang Peradilan Umum. 